\title{
Peningkatan Soft Skills Pribadi Konselor Mahasiswa BKI Melalui Career Development Program (CDP)
}

\section{Triyono, Syakirin Al-Ghozaly, Vera Imanti}

\author{
IAIN Surakarta \\ $e$-mail: triyonoalarief82@iain-surakarta.ac.id
}

Submitted: 05-10-2018, Revised: 24-11-2018, Accepted: 24-12-2018

\begin{abstract}
Soft skills are a set of abilities related to adjustments to oneself, others, and the environment. The counselor's personal soft skills mean the abilities or personal competencies possessed by a counselor. This study aims to determine how much the Career Development Program (CDP) influences in developing the counselor's personal soft skills of BKI students. The design of this research is quantitative experimental, using the preexperimental design method with the type of pre-test and post-test one group design. The population of this study were the students of Islamic Guidance and Counseling (BKI) IAIN Surakarta 2015/2016, 2016/2017, and 2017/2018 academic years. The sample in this study were 90 students by taken in 3 classes in each academic year, through stratified cluster random sampling. Measurement of the counselor's personal soft skills using EPPS psychological instruments. The research results of the counselor's personal soft skills of BKI students before and after being given Career Development Program (CDP) training, both in the second semester, 4th semester and 6 th semester students groups showed significant differences. The results of paired $t$-test analysis obtained the pretest and posttest values with sig values $=0.000<0.05$. This means that the Career Development Program $(C D P)$ has a significant effect on improving the counselor's personal soft skills of BKI students. The Career Development Program $(C D P)$ is a model for the development and improvement of personal counselor's soft skills that are effective for the students of BKI IAIN Surakarta.
\end{abstract}

Keywords: Career Development Program (CDP); Counselors; Personal Soft Skills Counselors

Abstrak: Soft skills merupakan seperangkat kemampuan yang berkaitan dengan penyesuaian terhadap diri sendiri, orang lain, serta lingkungan. Soft skills pribadi konselor berarti kemampuan atau kompetensi kepribadian yang dimiliki oleh seorang konselor. Penelitian ini bertujuan untuk mengetahui seberapa besar pengaruh Career Development Program (CDP) dalam pengembangan soft skill pribadi konselor mahasiswa BKI. Jenis penelitian ini adalah kuantitaftif eksperimen, dengan menggunakan metode pre experimental design dengan jenis pre test and post test one group design. Populasi penelitian adalah mahasiswa Bimbingan dan Konseling Islam (BKI) IAIN Surakarta tahun akademik 2015/2016, 2016/2017, dan 2017/2018. Sampel dalam penelitian ini adalah 90 mahasiswa atau diambil 3 kelas setiap angkatan tahun akademik, melalui stratified cluster random sampling. Pengukuran soft skill pribadi konselor menggunakan instrumen psikologi EPPS. Hasil analisis penelitian soft skill pribadi konselor mahasiswa BKI sebelum dan sesudah diberikan pelatihan Career Development Program (CDP), baik pada kelompok mahasiswa semester 2, semester 4, dan semester 6 menunjukkan perbedaan bermakna. Hasil analisis paired t-test diperoleh nilai pretest dan postest dengan nilai sig. $=0.000<0.05$. Artinya, Career Development Program (CDP) berpengaruh secara signifikan untuk meningkatkan soft skill pribadi konselor mahasiswa BKI. Career Development Program (CDP) menjadi model pengembangan dan peningkatan soft skill pribadi konselor yang efektif bagi mahasiswa BKI IAIN Surakarta.

Kata kunci : Career Development Program (CDP); Konselor; Soft Skills Pribadi Konselor

\section{Pendahuluan}

Konselor merupakan profesional dalam bidang bimbingan dan konseling dan telah memperoleh latihan dan pengalaman untuk membantu agar klien memecahkan kesulitannya. Bimbingan dan konseling merupakan aktivitas interaksi timbal-balik, di mana terjadi relasi antara konselor dan konseli dalam rangka untuk membantu konseli menyelesaikan masalah, karena di dalamnya terjadi hubungan yang saling mempengaruhi(Fuad, 2009). Dalam proses bimbingan dan konseling, seorang konselor harus memiliki berbagai prasyarat atau kapasitas tertentu yang dibutuhkan dalam upaya membantu menyelesaikan masalah yang dihadapi oleh konseli. Kapasitas inilah yang menentukan kualitas konselor. 
Kualitas konselor adalah semua kriteria keunggulan termasuk aspek-aspek pribadi, aspek pengetahuan, aspek wawasan, aspek keterampilan, dan nilai-nilai yang dimiliki konselor, yang akan menentukan efektivitas dan keberhasilan proses bimbingan dan konseling. Salah satu kualitas yang penting untuk dibicarakan adalah kualitas pribadi konselor, yang berkaitan dengan kompetensi yaitu menyangkut segala aspek kepribadian dan menentukan efektivitas konseling (Willis, 2007). Cavanagh (dalam Putri, 2016) menyebutkan setidaknya ada tiga isu sentral dalam mendiskusikan tentang kualitas pribadi konselor, yaitu: pengetahuan, keterampilan dan kepribadian. Dari ketiga hal tersebut kepribadian merupakan hal yang paling penting, meskipun aspek yang lain juga memiliki peran penting dan merupakan satu kesatuan yang tidak dapat dipisahkan.

Dengan kata lain, efektivitas dan keberhasilan proses konseling akan sangat dipengaruhi oleh besarnya modal kompetensi yang dimiliki oleh konselor. Modal ini meliputi dua aspek, yaitu hard skills dan soft skills. Hard skills lebih terfokus kepada pengetahuan bidang tertentu yang memuat keterampilan teknis pada proses, alat, atau teknik. Kemampuan tersebut biasanya diperoleh melalui pendidikan atau perkuliahan formal atau dari buku (Sukhoo, 2005). Adapun soft skills adalah kemampuan-kemampuan yang dimiliki individu yang ditunjukkan dengan kemampuan berinteraksi terhadap dirinya sendiri, orang lain serta lingkungan. Soft skills meliputi komunikasi efektif, berpikir kreatif dan kritis, membangun tim, kepercayaan diri serta kemampuan lainnya yang terkait kapasitas kepribadian individu.

Hard skills dan soft skills adalah kemampuan yang dimiliki setiap mahasiswa/lulusan perguruan tinggi, tidak terkecuali di PTAI/PTAIN. Kedua kemampuan ini menunjang keberhasilan lulusan untuk sukses atau bersaing dalam karirnya ke depan. menyebutkan bahwa hard skills dan soft skills secara bersama berpengaruh besar terhadap kinerja karyawan dalam melakukan pekerjaannya. Oleh karena itu, penting untuk mengembangkan soft skills sebagai pendukung hard skills. Kemampuan soft skills membekali mahasiswa dalam prestasi hidup di masa depan yang menuntut penyiapan sumber daya manusia yang siap kerja dan professional (Widayanti, 2012).

Hard skills dan soft skills meskipun sama-sama penting, pengajaran soft skills bukan menjadi prioritas dalam sistem pendidikan kita, yang lebih mengutamaan pengajaran atau penguasaan ilmu-ilmu pengetahuan dan teknologi (hard skills). Sailah (2008) menyebutkan bahwa ada perbedaan kebutuhan, pengembangan dan sudut pandang terhadap hard skills dan soft skill pada dunia kerja dengan perguruan tinggi pada saat ini. Sailah menyebut rasio kebutuhan soft skills dan hard skill di dunia kerja berbanding terbalik dengan pengembangannya di perguruan tinggi. Dalam praktiknya, sistem pendidikan di Indonesia saat ini, khususnya di perguruan tinggi, porsi pengembangan soft skills hanya diberikan rata-rata 10\% dalam kurikulumnya, 90\% lainnya berisi hard skills.

Konselor merupakan salah satu profil lulusan Jurusan Bimbingan dan Konseling Islam (BKI) IAIN Surakarta, dengan keunggulan kompeten, berakhlakul karimah, dan

terintegrasi dengan nilai kearifan lokal dan keindonesiaan. Guna mendukung profil lulusan tersebut, Prodi BKI, mendidik mahasiswanya untuk memiliki keahlian hard skills dan soft skills. Haryati (dalam Baedhowi, 2015) menyebutkan ada empat strategi untuk meningkatkan hard skills dan soft skills mahasiswa yaitu: (1) integrasi dalam pembelajaran, yaitu menyatukan dan saling berkaitan antara teori dan pengalaman lapangan, juga lingkungan pembelajaran (2) pemberdayaan dosen, diperlukan keluasan wawasan dan dorongan positif dari tenaga pengajar (3) optimalisasi kegiatan mahasiswa, yaitu dukungan yang positif terhadap kegiatan-kegiatan mahasiswa dalam rangka meningkatkan kompetensi diri serta masyarakat, (4) link and match dan kolaborasi dengan mitra kerja, juga memberikan kesempatan belajar kerja pada mahasiswa, agar juga memahami situasi kerja dan kemampuan berinteraksi.

Soft skills pribadi konselor berarti kemampuan atau kompetensi kepribadian yang dimiliki oleh seorang konselor. Pelayanan bimbingan dan konseling berkaitan dengan 
pembentukan perilaku, pola berpikir dan kepribadian klien. Melalui konseling diharapkan terbentuk perilaku dan pemikiran positif dan kepribadian yang baik pula dalam diri klien. Konselor yang menguasai kompetensi kepribadian yang positif tentunya dapat menjadi contoh teladan yang baik kepada konseli karena terlihat konsistensi antara saran dan perilaku. Di samping itu konselor yang menguasai kompetensi kepribadian dengan baik dapat meningkatkan keberhasilan proses bimbingan dan konseling untuk membantu dan mengarahkan klien menyelesaikan masalah pribadinya (Fatmawijaya, 2015).

Tentang pentingnya kualitas pribadi konselor, maka pribadi konselor yang berkualitas merupakan hal yang esensial dalam sebuah konseling untuk mencapai keberhasilan konseling yaitu terjadinya pemahaman pada klien terhadap permasalahan yang dihadapi termasuk solusinya (Putri, 2016). Hal ini dikarenakan bahwa konselor merupakan instrument dalam aktivitas konseling, sehingga keberhasilan terletak pada pribadi konselor. Sementara, menurut Fuad pengembangan pribadi konselor harus ditinjau dari beberapa aspek. Menurutnya, efektifitas bimbingan konseling sangat ditentukan oleh pribadi konselor, kualitas pribadi konselor perlu dimaksimalkan dan diutamakan dalam porsi pendidikan konselor, pribadi konselor yang berkualitas juga lebih ditunjukkan dalam menyikapi sesuatu; nilai-nilai yang dianut; perilaku yang tampak, serta perilaku dari respon tertentu; dan spiritualitas konselor, dibutuhkan pelatihan diri yang bermuatan psiko-spiritual-edukasi bagi konselor (Fuad, 2009). Ragam kegiatan yang variatif dan terarah dalam proses belajar mengajar berdampak pada peningkatan soft skills mahasiswa, seperti kerja sama, pengambilan keputusan, keterampilan berkomunikasi, disiplin, manajemen waktu, dan kejujuran. Selain itu juga dapat meningkatkan aktivitas belajar, dan meningkatkan hasil belajar (Sudiana, 2012).

Pengembangan soft skills pribadi konselor pada mahasiswa BKI di IAIN Surakarta, selain berupa pengintegerasian dengan kegiatan akademis, seperti perkuliahaan atau praktikum, dapat juga dilakukan dengan membuat program berupa Career Development Program (CDP) yang secara khusus memfasilitasi mahasiswa dalam pengembangan soft skills pribadinya. Dalam hal implemansi, pelaksanaan Career Development Program $(C D P)$ di tingkat Fakultas atau Prodi, baru dilakukan saat mendekati wisuda. Fokus utama program ini adalah pembekalan kesiapan kerja mahasiswa pasca lulus kuliah. Permasalahan yang kemudian muncul adalah terkait dengan efektifitas hasil, utamanya tentang peningkatan soft skill mahasiswa jika hanya diberikan di akhir proses menjadi mahasiswa.

Dikarenakan pembentukan dan pengembangan soft skills tidak dapat dilakukan secara instan, pelaksanaan Career Development Program $(C D P)$ perlu kemudian dilakukan secara berjenjang/bertahap dan berkelanjutan. Misalnya dengan diberikan kepada mahasiswa di semester awal perkuliahan (semester 2), pertengahan perkuliahan (semester 4), dan akhir perkuliahan (semester 6). Masing-masing tahapan ini akan disesuaikan dengan tingkat kebutuhan mahasiswa, misalnya di awal semester isi materi terkait motivasi dan kedisiplinan, kemudian di akhir perkuliahan isi materi terkait kewirausahan dan kesiapan menghadapi dunia kerja.

Program ini dilaksanakan secara bertahap, yaitu diawali dengan memaparkan pemahaman hingga pada akhirnya mahasiswa mampu mengevaluasi diri terkait dengan perubahan sikapnya. Banyak mahasiswa yang kurang mengerti cara mengembangkan diri utamanya soft skill, sehingga mahasiswa masih perlu diberikan arahan, pemahaman, kesempatan dan evaluasi. Hal-hal tersebut dapat dilihat dari perilaku yang tampak baik sikap di kelas, kehidupan sehari-hari, tugas-tugas praktikum, serta mengevaluasi diri dari setiap perubahan perilakunya. Termasuk pemahaman pentingnya meningkatkan perilaku positif, utamanya soft skill yang nantinya akan berkaitan dengan keahlian dalam konseling. 


\section{Metode Penelitian}

Penelitian ini menggunakan metode penelitian kuantitaftif eksperimen dengan menggunakan metode pre experimental design dengan jenis pre test and post test one group design. Metode ini diberikan pada satu kelompok saja tanpa kelompok pembanding (kontrol). Dalam penelitian ini terdapat dua variabel yang akan diteliti, yait: Career Development Program (CDP) sebagai variabel bebas, sedangkan Soft skills pribadi konselor sebagai variabel tergantung. Penelitian ini bertujuan untuk mengetahui apakah terdapat perbedaan kualitas soft skill pribadi konselor mahasiswa BKI sebelum dan sesudah mengikuti Career Development Program (CDP). Populasi dalam penelitian ini mahasiswa BKI IAIN Surakarta tahun akademik 2015/2016, 2016/2017, dan 2017/2018. Sampel dalam penelitian ini adalah 90 mahasiswa atau diambil 3 kelas setiap angkatan tahun akademik, dengan pertimbangan masing-masing kelas terdiri dari 30 mahasiswa, dengan teknik stratified random sampling. Alat ukur yang digunakan dalam penelitian ini menggunakan Edward Personal Preference Schedule Test atau Tes EPPS. Tes EPPS merupakan tes kepribadian yang terdiri atas pilihanpilihan jawaban yang mencerminkan diri seorang individu. Dalam Tes EPPS ini ada 15 aspek kepribadian yang diukur, dapat di lihat pada table 1 .

Tabel 1. Aspek kepribadian pada tes EPPS

\begin{tabular}{|c|c|c|}
\hline No & Aspek & Penjelasan \\
\hline 1 & Achievement & $\begin{array}{l}\text { Usaha untuk menunjukkan prestasi, baik di bidang kerja maupun } \\
\text { akademik. }\end{array}$ \\
\hline 2 & Deference & $\begin{array}{l}\text { Penyesuaian diri, adanya kemauan untuk menyesuaikan diri } \\
\text { mengikuti perintah atau aturan. }\end{array}$ \\
\hline 3 & Order & $\begin{array}{l}\text { Keteraturan tugas, adanya kebutuhan untuk keteraturan di dalam } \\
\text { bekerja. }\end{array}$ \\
\hline 4 & Exhibition & Usaha untuk menunjukkan diri kepada orang lain. \\
\hline 5 & Autonomy & Kemandirian, kecenderungan berusaha untuk berdiri sendiri. \\
\hline 6 & Affiliation & kecenderungan untuk berafiliasi dengan orang lain. \\
\hline 7 & Intraception & $\begin{array}{l}\text { Kemampuan berempati, kecenderungan untuk beraffiliasi dengan } \\
\text { orang lain. }\end{array}$ \\
\hline 8 & Succorance & kecenderungan untuk mendapatkan bantuan dari orang lain. \\
\hline 9 & Dominance & Kemauan untuk menguasai orang lain. \\
\hline 10 & Abasement & Kompromi, kemauan untuk mengalah (kompromi). \\
\hline 11 & Nurturance & Perhatian, kemauan untuk menyenangkan orang lain. \\
\hline 12 & Endurance & $\begin{array}{l}\text { Ketekunan, ketahanan dalam mengatasi rintangan-rintangan dalam } \\
\text { menyelesaikan pekerjaan. }\end{array}$ \\
\hline 13 & Heterosexual & kecenderungan dalam kehidupan seksual. \\
\hline 14 & Change & Keinginan untuk mengadakan perubahan. \\
\hline 15 & Aggression & Kecenderungan untuk berperilaku agresif \\
\hline
\end{tabular}

Dari 15 aspek tersebut, peneliti hanya menggunakan 9 aspek saja, hal ini disesuaikan dengan softskill pribadi konselor, yaitu: achievement (berprestasi), deference (penyesuaian diri), order (keteraturan tugas), autonomy (kemandirian), Intraception berempati), abasement (kompromi), nurturance (perhatian), change (perubahan), endurance (ketahanan atau ketahanan dalam mengatasi rintangan-rintangan dalam menyelesaikan pekerjaan).

Jumlah soal dalam tes EPPS ini terdiri dari 225 pasang pernyataan-pernyataan. Tentang interpretasi hasil Tes EPPS dapat dilihat pada table 2. 
Tabel 2. Interpretasi Skor Presentil EPPS

\begin{tabular}{ccc}
\hline Persentil & Interpretasi & T Skor \\
\hline 97 ke atas & Sangat tinggi & 70 ke atas \\
$85-96$ & Tinggi & $60-69$ \\
$17-84$ & Rata-rata & $41-59$ \\
$4-6$ & Rendah & $31-40$
\end{tabular}

3 ke bawah Sangat rendah 30 ke bawah

Pengujian hipotesis dilakukan dengan Uji T atau Paired Sample T Test, yang digunakan untuk uji perbedaan rata-rata dari variabel yang diteliti sebelum dan setelah dilakukan pelatihan dengan asumsi data berdistribusi normal. data ini menggunakan bantuan program SPSS (Statistical Product and service solution) 16 For Windows Program.

\section{Hasil dan Pembahasan}

Proses pelayanan bimbingan dan konseling berkaitan dengan pembentukan perilaku, cara berpikir dan kepribadian klien. Soft skills pribadi konselor berarti kemampuan atau kompetensi yang dimiliki oleh seorang konselor. Konselor yang menguasai kompetensi kepribadian secara tepat dapat mendukung dan mempengaruhi keberhasilan proses pelayanan bimbingan dan konseling untuk membantu klien dalam menghadapi, memahami, dan menyelasaikan masalahnya. Data tentang nilai rata-rata soft skills pribadi konselor mahasiswa BKI berada pada kategori rata-rata (cukup), atau berada dalam rentang skor 41-59. Mengingat tugas dan tanggung jawab konselor dan akan bersinggungan dengan perilaku dan kepribadian klien, soft skills pribadi perlu ditingkatkan.

Soft skill pada aspek achievement (berprestasi) berdasarkan hasil penelitian, baik pada kelompok mahasiswa semester 2, 4, atau 6 diperoleh nilai $\mathrm{p}<0,00$. Artinya terdapat perbedaan sebelum (pretest) dan sesudah (post test) mahasiswa mengikuti kegiatan Career Development Program (CDP). Kondisi ini membuktikan bahwa, mahasiswa Bimbingan dan Konseling Islam menunjukkan dorongan yang kuat untuk berprestasi, serta kemampuan menunjukkan keberhasilan menyelesaikan tugas-tugas yang diberikan kepadanya.

Murray menyatakan need for achievement atau kebutuhan berprestasi, yakni hasrat atau tendensi untuk mengerjakan dan menyelesaikan tugas-tugas yang membutuhkan pemikiran dan strategi dengan cepat dan sebaik mungkin (Purwanto, 1993). Individu dengan motivasi berprestasi yang tinggi untuk mempelajari dan memahami sesuatu akan cenderung memiliki tingkat kepercayaan diri yang baik, bertanggung jawab, berusaha mencapai basil yang maksimal, aktif dalam kehidupan sosial, memilih teman yang memiliki pemikiran dan semangat yang sama, serta daya tahan yang baik menghadapi tekanan-tekanan.

Proses pengembangan karir pada aspek achievement, hal pertama yang dilakukan adalah menaksir kebutuhan. Pada tahap ini mahasiswa semester 2 dan 4 mendapatkan materi tentang motivasi berprestasi. Ditanamkan pada mereka tentang pentingnya meraih prestasi. Prestasi yang dimaksudkan tidak selalu mengacu pada nilai akademis saja. Tetapi juga tentang prestasi dalam berperilaku. Misalnya, mahasiswa belum disiplin untuk bersikap, maka ditingkatkan agar lebih disiplin lagi. Ukuran dan standarisasi pencapaian prestasi masing-masing individu akan berbeda, sehingga yang ditanamkan adalah kesadaran untuk meningkatkan yang telah 
dikuasi saat ini. Hampir sama dengan kelompok mahasiswa semester 2 dan 4, mahasiswa semester 6 pun melewati tahapan yang sama. Perbedaannya adalah mereka lebih dipahamkan tentang tantangan berprestasi untuk melewati tugas akhir, kemudian gambaran dunia kerja.

Tahap kedua yaitu kesempatan karir. Memaparkan kebutuhan dalam berkarir dilanjutkan diberikan pemahaman bahwa mahasiswa semester 2 dan 4 mendapatkan kesempatan untuk meningkatkan kemampuan yang telah di miliki dalam bentuk kesempatan menuntut ilmu, kesempatan belajar, juga kesempatan berorganisasi dengan mengikuti kegiatan-kegiatan organisasi yang ada. Sedangkan pada semester 6 selain kesempatan dalam meningkatkan nilai akademis. Mereka juga mulai mencari kesempatan untuk meningkatkan kemampuan dalam melakukan bimbingan dan konseling. Selanjutnya tahapan yang ketiga adalah penyesuaian antara kebutuhan dan kesempatan. Setelah mereka memahami apa saja kebutuhan prestasi yang akan ditingkatkan, maka mereka pun akan mencari kesempatan yang dapat dilakukan secara positif.

Soft skill pada aspek Autonomy atau kemampuan untuk mandiri, kecenderungan untuk berafiliasi dengan orang lain, berdasarkan hasil penelitian pada kelompok mahasiswa semester 2, 4, dan 6 memperoleh nilai $\mathrm{p}<0,00$. Artinya terdapat perbedaan sebelum dan sesudah mahasiswa mengikuti kegaitan Career Development Program (CDP). Kemandirian adalah suatu proses tumbuh dan berkembang yang berkaitan dengan kemampuan menyelesaikan tugas-tugasnya sendiri tanpa bantuan orang lain (Drost, 1998). Kemandirian merupakan kemampuan mengatur keperluan diri sendiri sesuai dengan hak dan kewajibannya, serta tidak tergantung pada orang lain sampai batas kemampuannya, mampu bertanggung jawab atas keputusan, tindakan dan perasaannya sendiri serta mampu memilih dan menggunakan pola perilaku secara relevan. Dengan kata lain, mandiri berarti bebas untuk bertindak sesuai keinginan. Mampu menolak paksaan dan melawan batas yang diberikan. Menentukan diri sendiri dan tidak tergantung pada orang lain (Sukadji, 1986).

Adanya perbedaan sikap setelah mengikuti kegiatan Career Development Program $(C D P)$ menunjukkan bahwa, mahasiswa BKI memiliki keinginan kuat menyelesaikan tugasnya sendiri, serta tidak tergantung pada orang lain dalam mengambil keputusan, berpendapat, serta menentukan pendirian. Meskipun kenyataannya pada beberapa mahasiwa ditemukan adanya kecenderungan membutuhkan intervensi orang lain, dan kesulitan dalam mengambil keputusan.

Tahap pertama peningkatan soft skill pada aspek autonomy adalah memberikan pemahaman akan kebutuhan-kebutuhan untuk lebih mandiri. Menjadi mahasiswa awal, dalam hal mahasiswa semester 2 artinya harus siap mandiri sebab jauh dari orang tua. Mandiri juga dalam menentukan perilaku dengan tidak bergantung pada orang lain, dan juga dalam berpikir. Mahasiswa semester 4 dan 6 mendapatkan materi pengembangan karir pada tahap pertama ini dengan pemahaman kebutuhan untuk lebih mandiri dalam menentukan sikap dan perilaku. Terutama yang berkaitan dengan bimbingan dan konseling. Adapun tahap kedua adalah kesempatan karir, yaitu kesempatan untuk lebih mandiri yang telah didapatkan oleh mahasiswa secara umum. Namun kesempatan untuk berani mandiri dengan mencoba melatih keahlian, mandiri dalam mengembangkan keilmuan tidak semua mahasiswa memahami. Dengan demikian pada tahap kedua ini juga ditanamkan mengenai kesempatan untuk meningkatkan kemandirian. Selanjutnya memaparkan penyesuaian kebutuhan dan kesempatan terkait dengan kemandirian.

Soft skill pada aspek Intraception atau kemampuan berempati, kecenderungan untuk berafiliasi dengan orang lain berdasarkan hasil penelitian di atas, baik pada kelompok mahasiswa semester 2, 4, dan 6 memperoleh nilai $\mathrm{p}<0,00$. Artinya terdapat perbedaan sebelum dan sesudah mengikuti pelatihan Career Development Program (CDP). Menurut Carlekhuff (dalam Gunawan, 2001) terdapat sembilan karakterisitik pribadi konselor, di mana akan menumbuhkan kesadaran pada klien, salah satunya adalah empati. Empati adalah kemampuan 
untuk memahami kondisi orang lain dengan cara ikut merasakan dan mencoba membayangkan menempatkan dirinya pada posisi orang tersebut untuk mengerti cara pandang serta perasaan ketika mengalami permasalahan yang dihadapi (Yeni Rahmawati, 2006).

Dengan kata lain, empati merupakan salah satu kompetensi konselor yaitu kemampuan untuk ikut merasakan secara tepat apa yang dirasakan dan dialami oleh orang lain dan mengkomunikasikan persepsinya. Seseorang yang memiliki tingkat empati tinggi akan cenderung menunjukkan sikap membantu secara nyata dengan bantuan yang berarti dalam berinteraksi dengan orang lain. Sementara mereka yang rendah empatinya menunjukan sikap yang acuh, cenderung tidak membangun suatu relasi dan interaksi yang baik terhadap orang lain, kaitannya dengan interaksi antar pribadi.

Empati mengacu pada keadaan identifikasi kepribadian dan permasalahan yang lebih mendalam kepada seseorang, sehingga seseorang yang berempati dalam sesaat melupakan atau kehilangan dirinya sendiri. Penekanan empati dalam hal ini adalah kemampuan mendalami perasaan orang lain dapat membuat tenggelam dan larut dalam situasi perasaannya. Hal ini biasa disebut dengan resonansi perasaan, yaitu mampu memahami perasaan negatif atau positif seolah-olah emosi tersebut dialami sendiri. Kemampuan berempati seseorang dibutuhkan untuk menjadi kunci keberhasilan dalam meningkatkan kompetensi sosial, yaitu bergaul dan bersosialisasi di masyarakat.

Tentang empati, mengatakan bahwa untuk dapat meningkatkan kemampuan empati, hal yang paling penting dan mendasar adalah pemahaman adanya perbedaan antara individu. Seseorang yang empatik memiliki sifat dan keahlian-keahlian yang terkait dengan personal komunikasi yaitu komunikasi dua arah dan komunikasi empatik, cara pandang dan peka dalam berinteraksi dengan orang lain, karena orang yang empatik akan memiliki kemampuan memahami atas kondisi dan keadaan orang lain. Kemampuan empati perlu dimiliki seorang konselor (Eisenberg and Strayer, 1987). Dengan adanya kompetensi empati akan mampu mendorong konselor untuk melihat permasalahan lebih dalam dan jeli, sehingga dapat menempatkan objektivitas dalam menguraikan masalah dan menemukan problem solvingnya.

Memahamkan akan kebutuhan untuk berempati ditanamkan mulai dari diri sendiri. Mahasiswa semester 2 dipahamkan konsep kepedulian memahami kondisi orang lain di sekitarnya. Mahasiswa semester 4 dan 6 mulai ditanamkan untuk berempati, di mana berempati ini tidak lagi menjadi sebuah dasar kepedulian manusia semata, namun juga masuk kepada keahlian yang harus dimiliki mahasiswa BKI.

Selanjutnya adalah tahapan kesempatan karir. Kesempatan mengembangkan keahlian dalam berempati, menanamkan bahwa kesempatan dapat mereka dapatkan di mana saja. Baik di dalam lingkungan terdekat maupun lingkungan luar. Bagi semester 4 dan 6 utamanya dapat melakukan banyak praktek konseling, misalnya melalui organisasi-organisasi kampus, serta fasilitas-fasilitas akademis lain yang mendukung. Tahap selanjutnya adalah tahap penyesuaian antara keduanya. Yaitu menumbuhkan kesadaran akan kebutuhan berempati. Kemudian dengan kesempatan yang ada, apakah telah sesuai target masing-masing individu. Pada tahap ini membantu mahasiswa memahami dalam menyesuaikan dua tahap sebelumnya. Tahap ini juga bisa dijadikan bahan evaluasi pribadi, apakah kebutuhannya telah sesuai, dengan kesempatan yang ada apakah tercapai. Dengan demikian kembali pada siklus awal, mahasiswa kembali memetakan dirinya. Dalam hal profesi konselor sebagai social helper, kemampuan empati mahasiswa BKI cukup tinggi atau berada pada rentang skor 60-69. Dengan kata lain, mahasiswa sudah mampu membedakan simpati dan empati, sudah mampu membatasi diri dan perasaannya, sehingga tidak larut dan terbawa pada situasi dan perasaan orang lain (konseli).

Soft skill pada aspek order atau keteraturan tugas termasuk di antaranya adalah menyusun hal-hal secara rapi dan menjaga kebersihannya, berdasarkan hasil penelitian diperoleh $\mathrm{p}<0,000$. Artinya terdapat perbedaan sebelum dan sesudah mengikuti pelatihan Career Development Program $(C D P)$. Dengan melihat rata-rata aspek order yang pada 
katagori rata-rata atau berada pada rentang skor 41-59, dapat disimpukan bahwa berkaitan dengan kinerja, sebagian mahasiswa BKI mampu menunjukan keteraturan atau keinginan yang tinggi dalam mengerjakan dan menyelesaikan tugas.

Proses pengembangan karir pada aspek order, tahap pertama mahasiswa dibantu untuk memahami kebutuhan akan keteraturan tugas. Akan berbeda tugas dari semester 2, 4, dan 6. Di mana semester 2 berada pada tahap yang paling ringan. Sedangkan semester 6 berada pada tahap yang paling tinggi. Tahap yang paling tinggi adalah teratur dalam tugas, manajemen waktu, serta teratur dalam bertutur kata, baik dalam tugas-tugas kuliah, praktikum, maupun organisasi yang akan lebih mengembangkan kesadaran untuk meningkatkan kualitas diri utamanya dengan keteraturan tugas. Pada tahap kedua yaitu kesempatan karir, mahasiswa diberikan wawasan untuk menemukan kesempatan dalam mengembangkan kemampuannya dalam keteraturan tugas. Lanjut pada tahap ketiga, membantu memahamkan mahasiswa untuk menyeimbangkan antara kebutuhan dan kesempatan.

Soft skill pada aspek deference atau kebutuhan untuk menyesuaikan diri dalam mengikuti perintah atau aturan, berdasarkan hasil penelitian diperoleh $\mathrm{p}<0,000$. Artinya terdapat perbedaan sebelum dan sesudah mengikuti pelatihan Career Development Program (CDP). Nilai rata-rata aspek deference yang pada katagori rata-rata atau berada pada rentang skor 4159. Hal ini menunjukkan bahwa mahasiswa BKI mampu mengenal, memahami, serta terlibat aktif dalam lingkungan kampus. Selain itu, menyadari akan kebutuhan untuk bekerjasama, mendukung, dan terbuka untuk mengikuti aturan yang telah ditetapkan dalam lingkungan baik formal maupun nonformal.

Tahap pertama peningkatan soft skills pada aspek deference, mahasiswa diberikan pemahaman untuk menyesuaikan diri baik pada lingkungan maupun pada situasi yang baru. Perkuliahan yang baru, mata kuliah baru, lingkungan yang baru, setiap mahasiswa dapat menyesuaikan diri dengan baik. Selain itu mahasiswa juga diminta untuk terlibat aktif baik dalam perkuliahan maupun pada organisasi yang mendukung kemampuan dalam memberikan bimbingan dan konseling. Setelah memahami kebutuhan untuk menyesuaikan diri, dilanjutkan pada tahapan kedua yaitu kesempatan karir. Mahasiswa peka terhadap situasi atau lingkungan yang baru, kemudian segera beradaptasi. Pada tahap ini mahasiswa selain memberikan respon juga menunjukkan sikap. Sedangkan pada tahap ketiga, mahasiswa dibantu untuk memahami penyesuaian antara kedua tahap, yaitu menyadari kebutuhannya kemudian diselaraskan dengan kesempatannya. Pada tahap ini semacam evaluasi dalam memantau sikap penyesuaian diri pada mahasiswa.

Soft skill pada aspek nurturance atau kebutuhan untuk memberikan perhatian pada orang lain, berdasarkan hasil penelitian diperoleh $\mathrm{p}<0,000$. Artinya terdapat perbedaan sebelum dan sesudah mengikuti pelatihan Career Development Program (CDP). Nilai rata-rata pada aspek nurturance ini berada pada kategori rata-rata, atau berada pada rentang skor 41-59. Hal ini menunjukkan bahwa mahasiswa BKI memiliki perhatian dan simpati terhadap orang-orang yang ada disekitarnya. Dengan terbiasa memberikan perhatian terhadap orang lain, maka dapat terus menumbuhkan perasaan iba, simpati, dan hasrat ingin menolong.

Nurturance adalah kebutuhan untuk memberikan perhatian dan kasih sayang terhadap orang-orang di sekitrnya. Seseorang yang memiliki nurturance yang baik akan memiliki sikap pribadi yang terbuka yaitu membuka diri untuk menerima masukan (kritik dan saran), mudah memberikan perhatian dan membantu orang lain, memiliki sikap santun, serta mampu untuk bersimpati. Dengan demikian akan sangat terbantu bagi mahasiswa BKI yang semakin meningkat aspek nurturance-nya untuk mengembangkan sikap pribadi konselor.

Pada tahap pertama pengembangan karir aspek nurturance, mahasiswa diminta untuk menemukan kebutuhan untuk memberikan perhatian pada orang lain. Kebutuhan ini dapat ditemukan dalam perkuliahan, kehidupan sehari-hari atau pada organisasi yang ditekuni. Pada tahap selanjutnya mahasiswa diberikan kesempatan untuk memberikan perhatian kepada orang 
lain. Pada perkuliahan biasanya dosen memberikan kesempatan mahasiswa untuk mengerjakan tugas yang sifatnya praktik lapangan. Kesempatan lain hadir pada kehidupan sehari-hari, selain itu pada organisasi yang ditekuni. Tahap terakhir adalah evaluasi, mahasiswa dibantu untuk memahami penyesuaian antara tahap pertama dan kedua. Apakah sudah sesuai antara kebutuhan dan kesempatan yang kemudian dimunculkan pada respon sikap dan perilaku.

Soft skill pada aspek change adalah kebutuhan dan keinginan untuk berubah. Pada hasil penelitian, aspek ini diperoleh $\mathrm{p}<0,000$. Artinya terdapat perbedaan sebelum dan sesudah mengikuti pelatihan Career Development Program (CDP). Nilai rata-rata mahasiswa BKI pada aspek change berada pada kategori rata-rata, atau berada pada rentang skor 41-59. Artinya, mahasiswa BKI memiliki kemampuan yang cukup baik dalam menerima perubahan.

Tentang change, dijelaskan bahwa kesiapan individu untuk berubah sebagai sikap komprehensif yang secara simultan dipengaruhi oleh isi (apa yang berubah), proses (bagaimana perubahan diimplementasikan), konteks (lingkungan di mana perubahan terjadi), dan individu (karakteristik individu yang diminta untuk berubah) yang terlibat di dalam suatu perubahan (Holt, Armenakis, Feild \& Harris 2007). Kesiapan adalah tidak sekedar pemahaman akan perubahan, kesiapan adalah tidak sekedar yakin terhadap perubahan yang terjadi, kesiapan merupakan kumpulan dari pemikiran dan intensi pada usaha perubahan yang spesifik (Berneth, 2004).

Change menjadikan seseorang mudah untuk menyesuaikan diri, beradaptasi dan siap untuk menerima perubahan-perubahan yang terjadi di lingkungannya. Jika terkait dengan pekerjaan, maka seseorang mudah menerima perubahan ritme kerja, aturan, situasi, serta tantangan yang dihadapi. Hal ini juga menunjukkan minat yang tinggi terhadap pergaulan, yaitu mengenal banyak lingkungan baru serta berinteraksi dengan orang-orang yang ada disekitarnya.

Pada aspek change, tahap pertama yang dilakukan mahasiswa adalah memahami kebutuhan untuk kesiapan menghadapi perubahan. Situasi yang tidak selalu teratur, namun juga kondisional. Mahasiswa perlu menyadari pentingnya menguasai dan meningkatkan aspek ini. Karena jika tidak maka ia akan tertinggal dan tidak mengalami peningkatan yang signifikan. Pada tahap kedua yaitu kesempatan, mahasiswa diberikan kesempatan untuk mencari kebutuhannya kemudian meresponnya. Kondisi-kondisi yang cepat berubah dan harus cepat pula dalam menyesuaikan diri merupakan kesempatan mahasiswa untuk mengembangkan dirinya. Dapat mereka temukan ketika di perkuliahan, tugas praktik, kegiatan sehari-hari, maupun di dalam organisasi-organisasi yang ditekuninya. Selanjutnya adalah tahap evaluasi, di mana mahasiswa dibantu untuk memahami penyesuaian antara kebutuhan dan kesempatan yang didapatkan. Dari evaluasi ini, mahasiswa diharapkan semakin memahami kondisi dengan cepat lalu cepat pula dalam bersikap. Dengan memahami runtutan kondisi, mahasiswa dapat mengembangkan aspek kesiapan dalam menghadapi perubahan.

Soft skill pada aspek abasement adalah adanya kebutuhan untuk merendahkan diri kaitannya dengan toleransi, kompromi, serta menyesuaikan diri. Dari hasil penelitian, aspek ini diperoleh $\mathrm{p}<0,000$. artinya terdapat perbedaan sebelum dan sesudah mengikuti pelatihan Career Development Program $(C D P)$. Adapun nilai rata-rata pada aspek abasement ini berada pada kategori rata-rata, atau berada pada rentang skor 41 - 59. Di mana artinya bahwa mahasiswa BKI cukup dapat melakukan kompromi dalam menyikapi suatu situasi yang membutuhkan kesepakatan dari dua belah pihak. Selain itu, terkait dengan toleransi, dengan memahami kondisi orang lain maka dapat menyesuaikan diri dengan mengkomunikasikannya dengan baik. Akan tetapi perlu diwaspadai untuk aspek ini, karena jika terlalu kuat maka individu akan merasakan penyesalan dan merasa bersalah lebih mendalam.

Pada tahap pertama pengembangan karir aspek ini, mahasiswa diminta untuk memahami tentang aspek kompromi, atau kesepakatan dua belah pihak. Mahasiswa ditanamkan kebutuhan untuk berkompromi, bahwa sesuatu kondisi dapat didiskusikan. Setelah memahami kebutuhan 
untuk kompromi, mahasiswa diberikan kesempatan untuk mengembangkan diri terkait dengan kompromi. Pada perkuliahan, kesepakatan awal antara dosen dan mahasiswa merupakan keahlian dalam berkompromi. Selain itu ketika menghadapi klien pada praktikum, mahasiswa mencoba untuk berkompromi dengan klien. Pada kehidupan sehari-hari pun secara tidak sadar (dan disadarkan pada tahap pertama) mahasiswa melakukan dan melatih suatu kebutuhan komprominya.

Pada tahap evaluasi, mahasiswa dibantu untuk mengevaluasi penyesuaian antara tahap pertama dan tahap kedua. Apakah kebutuhannya dalam berkompromi telah mendapatkan kesempatan untuk dikembangkan. Jika telah sesuai selanjutnya mahasiswa diminta untuk menemukan kondisi seperti apa yang menghambatnya sehingga belum maksimal. Lalu setelah itu dicoba lagi. Perubahan-perubahan kategori yang tampak pada angka-angka dipengaruhi oleh perlakuan yang diberikan yaitu Career Development Program (CDP) dengan melalui proses yang bertahap. Tahapan tersebut yaitu memahami kebutuhan, kesempatan karir, dan penyesuaian antara keduanya.

\section{Simpulan}

Career Development Program (CDP) terbukti efektif meningkatkan soft skill pribadi konselor Mahasiswa BKI. Hal ini ditunjukkan dengan adanya perbedaan skor pada subjek sebelum diberi pelatihan dan sesudah diberi pelatihan. Kondisi ini dialami pada subjek penelitian, baik pada kelompok mahasiswa semester 2, 4, dan 6. Berdasarkan hasil uji T Paired Sample $T$ Test, diketahui bahwa sig. $=0,000<0,05$ atau Ho ditolak. Artinya, Career Development Program (CDP) berpengaruh secara signifikan untuk meningkatkan soft skill pribadi konselor mahasiswa BKI. Career Development Program (CDP) menjadi model pengembangan dan peningkatan soft skill pribadi konselor yang efektif bagi mahasiswa BKI IAIN Surakarta. Penerapan Career Development Program (CDP) secara berjenjang/bertahap dan berkesinambungan akan mempermudah membentuk karakter dan pribadi dari mahasiswa sejak awal yang akan dibentuk pribadinya sesuai dengan standar masing-masing jurusan atau fakultas. Atau akan lebih efektif hasilnya jika mahasiswa telah mendapatkan materi Career Development Program (CDP) sejak awal perkuliahan karena akan membentuk perilaku, kaitannya dengan soft skill pribadi yang harus terbentuk sebagai output lulusan Program Studi BKI, yaitu konselor.

\section{DAFTAR PUSTAKA}

Drost, 1998, Sekolah: Mengajar atau Mendidik?, Yogyakarta, Kanisius.

Eisenberg \& J. Strayer (1987). Affective and Cognitive Perspectives on Empathy. England: Cambridge University Press.

Fatmawijaya, Heru Andrian. (2015). "Studi Deskriptif Kompetensi Kepribadian Konselor yang Diharapkan Siswa." Psikopedagogia Vol. 4, No.2

Fuad, Muskinul. (2009). "Kualitas Pribadi Konselor: Urgensi dan Pengembangannya”. Jurnal Komunika, Vol.3 No.2.

Gall, Meredith D, Gall, Joyce P, \& Borg, Walter R. (2003). Educational Research, An Introduction (Seventh Ed). Boston: Allyn and Bacon.

Gunawan, Y. (1992). Pengantar Bimbingan dan Konseling: Panduan untuk Mahasiswa. Jakarta: Gramedia

Haryati, Sri. (16 April 2011). “Upaya Meningkatkan Soft Skills Mahasiswa di Perguruan Tinggi". Makalah Disajikan pada seminar ilmiah semesteran Korpri Subunit Kopertis Wilayah VI Jawa Tengah di Magelang.

Purwanto, Ngalim (1993). Psikolog Pendidikan, Bandung: PT. Remaja Rusada Karya. 
Putri, A. (2016). "Pentingnya Kualitas Pribadi Konselor dalam Konseling untuk Membangun Hubungan Antar Konselor dan Konseli." Jurnal Bimbingan Konseling Indonesia Vol. 1 No.1 Maret. Pontianak

Rahmawati, Yeni. (2006). Metode Pengembangan Sosial-Emosional. Jakarta: Universitas Terbuka

Sailah, I. (2008). Pengembangan Soft Skills di Perguruan Tinggi. Jakarta: Direktorat Jenderal Pendidikan Tinggi.

Sudiana, I.K. (2012). "Upaya Pengembangan Soft Skills Melalui Implementasi Model Pembelajaran Kooperatif untuk Peningkatan Aktivitas dan Hasil Belajar Mahasiswa pada Pembelajaran Kimia Dasar”. Jurnal Pendidikan Indonesia Vol.1 No.2 Oktober. Singaraja

Sukhoo, Aneerav, et. al. (2005). "Accomodating Soft skills in Software Project Management. Working Paper in Issues Informing Science and Information Technology." (Diakses tanggal 18 Desember 2017) [http://informingscience.org]

Widayanti, R. (2012). "Pengaruh Hard Skills dan Soft Skills terhadap Kinerja Karyawan." (Diakses tanggal 18 Desember 2017) [http://download.portalgaruda.org]

Willis, Sofyan S. (2007). Konseling Individual Teori dan Praktek. Bandung: Alfabeta. 
